\title{
PENGARUH KUALITAS PELAYANAN DAN BAGI HASIL TERHADAP MINAT MENABUNG NASABAH PADA TABUNGAN MARHAMAH PT BANK SUMUT KCP SYARIAH KARYA
}

\author{
Fitri Al Faqih \\ Politeknik Negeri Medan \\ Email: fitrial.faqih@gmail.com
}

\begin{abstract}
This study was conducted to determine the influence of the quality of service and for the results of interest saving customers to the Marhamah saving PT Bank Sumut KCP Syariah Karya. Variable independent in the study is interest saving customers on Marhamah saving whereas variable independent consists of the quality of service and for the results. Samples used in this study is as much as 87 customers. This study using data questioner as the primary then the results of data analyzed using the analysis of regressing double linear, by doing a partial test, $(t)$, simultaneous test $(f)$, the coefficient of determination, with a significance level of 5 percent $(a=0,05)$ processed using SPPS 23. The results of this study indicate the quality of the services and for the results of the significant effect on interest saving customers to the Marhamah saving viewed through the statistical test of $F$ with the value of significant of 0,002. The results of the statistical test showed that service quality has a positive influence and significant with a significance level of 0,002, and for the results to have a positive influence and significant with a significance level 0,058.
\end{abstract}

Keywords: The quality of service, for the results, the interest of saving the customers on the saving Marhamah.

\begin{abstract}
Abstrak
Penelituan ini dilakukan untuk mengetahui pengaruh kualitas pelayanan dan bagi hasil terhadap minat menabung nasabah pada tabungan marhamah PT Bank Sumut KCP Syariah Karya. Variabel dependen dalam penelitian ini adalah minat menabung nasabah pada tabungan marhamah sedangkan variabel independen terdiri dari kualitas pelayanan dan bagi hasil. Sampel yang digunakan dalam penelitian ini adalah sebanyak 87 nasabah. Penelitian ini menggunakan kuesioner sebagai data primer kemudian hasil datanya dianalisis menggunakan analisis regresi linear berganda, dengan melakukan uji parsial $(\mathrm{t})$, uji simultan $(\mathrm{F})$, dan uji koefisien determinasi, dengan tingkat signifikansi sebesar 5 persen $(\alpha=0,05)$ yang diolah menggunakan SPSS 23. Hasil penelitian ini menunjukkan kualitas pelayanan dan bagi hasil berpengaruh signifikan terhadap minat menabung nasabah pada tabungan marhamah yang dilihat melalui uji statistik $F$ dengan nilai signifikansi sebesar 0,002 . Hasil uji statistik $t$ menunjukkan bahwa kualitas pelayanan memiliki pengaruh positif dan signifikan dengan tingkat signifikansi sebesar 0,012 dan bagi hasil memiliki pengaruh positif dan signifikan dengan tingkat signifikansi sebesar 0,058.
\end{abstract}

Kata Kunci: Kualitas Pelayanan, Bagi Hasil, Minat Menabung Nasabah pada Tabungan marhamah 


\section{PENDAHULUAN}

Bank sebagai lembaga perantara keuangan melakukan mekanisme pengumpulan dan penyaluran dana secara seimbang sesuai dengan kententuan yang berlaku. Bank berdasarkan prinsip syariah, seperti hal konvensional, juga berfungsi sebagai lembaga intermediasi (intermediary instution), yaitu menyerap dana dari masyarakat dan menyalurkan kembali dana - dana tersebut kepada masyarakat yang membutuhkannya dalam bentuk fasilitas pembiayaan. Sistem operasional bank syariah dikembangkan berlandaskan Al-quran dan hadist nabi Muhammad SAW. Untuk menghindari sistem operasional bank dengan menggunakan sistem bunga, islam memperkenalkan prinsip - prinsip muamalah Islam. Sebagaimana di dalam Al-Quran Allah SWT berfirman pada Surah An-Nisa: 9

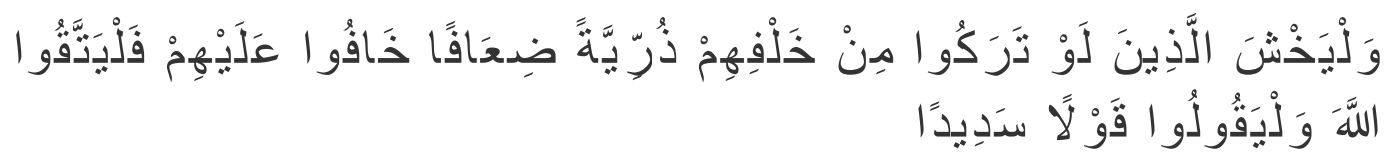

"Dan hendaklah takut kepada Allah orang-orang yang seandainya meninggalkan dibelakang mereka anak-anak yang lemah, yang mereka khawatir terhadap (kesejahteraan) mereka. Oleh sebab itu hendaklah mereka bertakwa kepada Allah dan hendaklah mereka mengucapkan perkataan yang benar".

Yang dimaksud ayat tersebut adalah Allah memerintahlan manusia untuk mengantisipasi dan mempersiapkan masa depan untuk keturunan baik secara rohani/iman maupun secara ekonomi. Hadist Riwayat Bukhari:

"Simpanlah sebagian dari harta kamu untuk kebaikan masa depan kamu, karena itu jauh lebih baik bagimu." Hadits ini menguatkan dengan secara tegas Nabi Muhammad saw menganjurkan untuk menabung.

Menghadapi persaingan antar lembaga keuangan syariah harus memberikan pelayanan terbaik agar menimbulkan minat nasabah untuk menabung, sehingga ketika nasabah minat untuk menabung maka nasabah akan terus menggunakan produk dan jasa bank syariah. Menurut berita Jakarta, Kompas.com dirilis pada tanggal 21-01-2019 Untuk meningkatkan minat menabung masyarakat pemerintah terus berupaya meningkatkan inklusi keuangan melalui lembaga terkait, salah satunya lewat Otoritas Jas Keuangan (OJK). OJK sudah mencanangkan hari menabung nasional. "Kita rencanakan akan ada hari Indoneisa Menabung. Jadi kita pingin supaya inklusi masyarakat Indonesia. Seluruh masyarakat Indonesia terutama pelajar itu semua nanti pu ya rekening" kata Deputi Komisioner Edukasi dan Perlindungan Konsumen OJK, Sarjito di Jakarta, Senin (21/1/2019).

Menurut berita MedanBisnis - Medan. Tabungan di perbankan Sumatera Utara (Sumut) pada tahun 2018 mencatatkan kinerja kurang baik. Data Bank Indonesia (BI) Perwakilan Sumut tahun 2018 mencatat tabungan perbankan Sumut mencapai Rp 87,7 triliun. Jumlah tersebut menurun 0,52\% dibandingkan tahun 2017. "Untuk DPK di perbankan Sumut, tabungan memang turun. Karena deposito masih tumbuh 2,93\% menjadi Rp 100 Triliun. Sementara giro tercatat senilai Rp 34,2 triliun dan bisa mencatatkan 
pertumbuhan sebesar 1,44\% dibandingkan tahun 2017" kata Pjs Kepala Perwakilan BI Sumut Hilman Tisnawan, Senin (11/3).

Pada PT Bank Sumut KCP Syariah Karya jumlah nasabah pada tahun 2016 sejumlah 129 nasabah dan terjadi kenaikan tapi tidak signifikan sejumlah 168 nasabah dan pada tahun 2018 terjadi kenaikan yang cukup signifikan sejumlah 386 nasabah.

Tabel 1. Rekapitulasi Nisbah Bagi Hasil dan Jumlah Nasabah Produk Dana Pihak Ketiga (Tabungan Marhamah) PT Bank Sumut KCP Syariah Karya

\begin{tabular}{|c|c|c|}
\hline Tabungan Marhamah & Jumlah Nasabah & $\begin{array}{l}\text { Nisbah Bagi Hasil / } \\
\text { Desember }\end{array}$ \\
\hline 2016 & 129 & $3.96 \%$ \\
\hline 2017 & 168 & $4.24 \%$ \\
\hline 2018 & 386 & $2.60 \%$ \\
\hline
\end{tabular}

Sumber: PT Bank Sumut KCP Syariah Karya

Menurut Rivai (2010:687), mudharabah adalah perjanjian antara pemilik dana dan pengelola dana untuk melakukan suatu kegiatan usaha tertentu, dengan pembagian keuntungan antara kedua belah pihak berdasarkan nisbah yang telah disepakati diantara kedua belah pihak tersebut.

Definisi teknis keuangan, akad mudharabah adalah akad kerjasama antara bank salaku pemilik dana (shahibul al maal) dengan nasabah selaku mudharib yang mempunyai keahlian atau keterampilan untuk mengelola suatu usaha yang produktif dan halal. Hasil keuntungan dari penggunaan dana tersebut dibagi bersama berdasarkan nisbah yang disepakati.

Dapat disimpulkan bahwa pengertian mudharabah adalah suatu transaksi penanaman dana atau investasi berdasarkan kepercayaan. Kepercayaan merupakan unsur penting dalam akad mudharabah karena pemilik dana tidak boleh ikut campur dalam suatu proyek yang dijalankan yang dibiayai dengan pemilik dana tersebut, kecuali hanya sebatas memberikan saran-saran dan melakukan pengawasan terkait dengan pengelolaan dana Muhammad (2014:240).

Menurut Juniawan (2014:02) yang berkesimpulan bahwa ada kebutuhan bagi bank Islam untuk menggunakan program kualitas layanan Islami.Alasan mengapa bank Islam harus sadar akan kualitas layanan adalah pertama, produk dan layanan bank Islam harus diterima sebagai produk dan layanan yang berkualitas tinggi oleh konsumen. Konsep kerja dalam Islam dianggap sebagai salah satu jenis ibadah. Kedua, menggunakan kualitas layanan dalam bank Islam menjadi penting karena hubungannya yang jelas dengan biaya, keuntungan, kepuasan konsumen, ingatan konsumen, serta kata-kata positif dari mulut konsumen. 
Hal lain yang bisa saja mempengaruhi minat menabung salah satunya ialah tingkat bagi hasil. menurut Nikensari (2012:24), bagi hasil adalah kerja sama antara dua pihak yang satu sebagai penyandang dana dan yang lain sebagai pengelola dimana hasil usahanya akan dibagi sesama sesuai nisbah yang telah disepakati, misalnya 50\%:50\% (akad mudharabah).

PT Bank Sumut KCP Syariah Karya telah melakukan upaya untuk mencapai minat menabung nasabah dengan memaksimalkan kualitas pelayanan dalam produk tabungan marhamah yang dapat mempengaruhi minat nasabah dalam menabung.

Kualitas pelayanan yang baik di suatu perusahaan akan menciptakan kepuasan bagi pelanggan. Salah satu tindakan untuk memuaskan pelanggan, yaitu dengan memberikan pelayanan dengan sebaik-baiknya. Pelayanan tersebut dapat berupa kecepatan dan ketepatan waktu dalam melayani pelanggan, tanggap terhadap keluhan pelanggan, serta memberikan pilihan solusi yang terbaik. Kenyataan ini bisa dilihat, bahwa ada beberapa hal yang dilakukan perusahaan dengan memberikan perhatian yang lebih pada kepuasan pelanggan. Fokus pada kepuasan pelanggan merupakan salah satu upaya dalam mempertahankan pelanggan.

\section{METODE PENELITIAN}

Jenis penelitian yang digunakan adalah kuantitatif deskriptif. Jenis data yang digunakan dalam penelitian ini adalah data kuantitatif, yaitu data yang berupa angka-angka yang dapat dihitung guna menghasilkan suatu penaksiran, yaitu berupa hasil jawaban dari kuesioner yang disebarkan kepada responden (Sugiyono, 2017:81). Penelitian yang akan dilakukan adalah untuk menguji hubungan variabel independen yaitu, Kualitas pelayanan (X1), bagi hasil (X2), terhadap variabel dependen yaitu minat menabung (Y).

Tempat penelitian yang digunakan pada penelitian ini adalah Bank Sumut KCP Syariah Karya. Penelitian ini akan menggunakan data-data dari bank serta data yang diperoleh dari pembagian kuesioner kepada nasabah bank tersebut. Penelitian ini akan dilakukan dari bulan Juni-Juli 20

Dalam penelitian ini populasi adalah seluruh nasabah tabungan marhamah pada PT Bank Sumut Kantor Cabang Pembantu Syariah Karya yang berjumlah 683 nasabah. Maka jumlah sampel yang diperoleh adalah:

$$
n=\frac{683}{1+683(0.1)^{2}}=87,22
$$

Melalui perhitungan rumus slovin diperoleh jumlah sampel sebesar 87,22 dibulatkan menjadi 87 sample. Kriteria sample pada penelitian ini adalah nasabah tabungan mudharabah pada PT Bank Sumut KCP Syariah Karya. 
Tabel 2. Variabel dan Indikator Penelitian

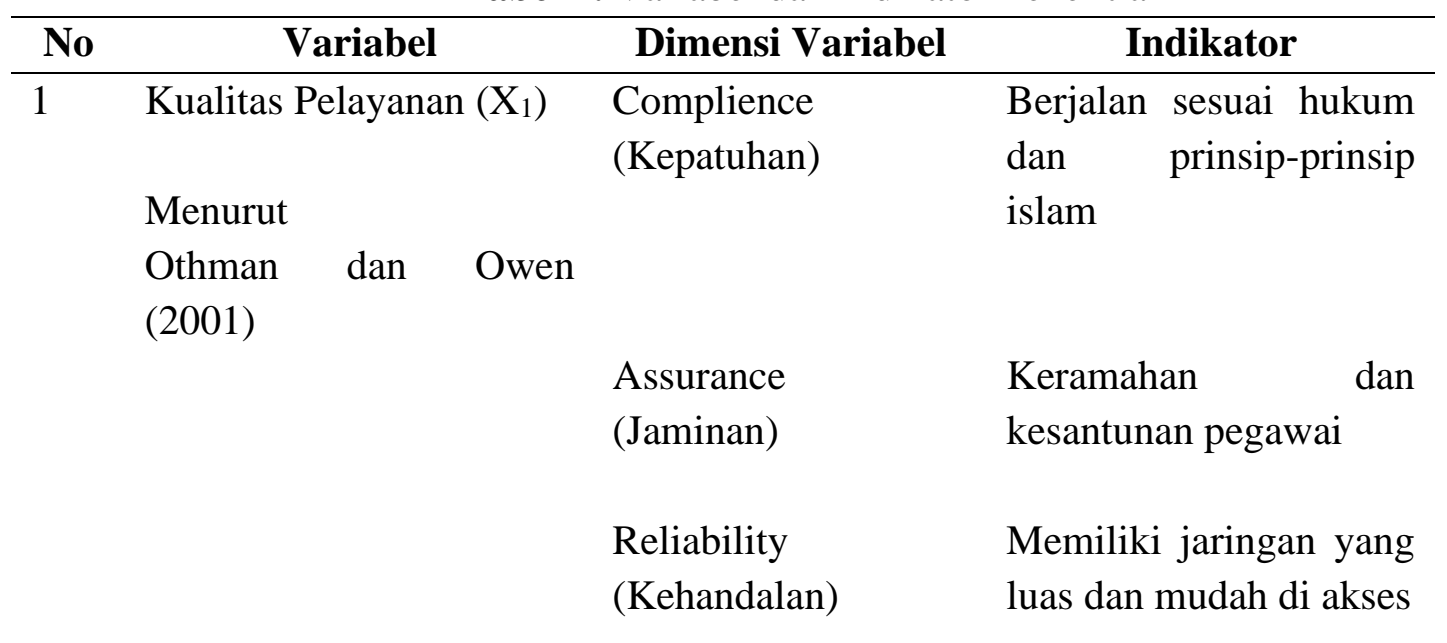

\begin{tabular}{|c|c|c|c|}
\hline & & $\begin{array}{l}\text { Tangible } \\
\text { (Keberwujudan) }\end{array}$ & $\begin{array}{lr}\text { Pelayanan } & \text { cepat dan } \\
\text { ketepatan } & \text { dalam } \\
\text { transaksi. } & \end{array}$ \\
\hline & & $\begin{array}{l}\text { Emphaty } \\
\text { (Empati) }\end{array}$ & $\begin{array}{l}\text { Produk layanan } \\
\text { tabungan mudharabah } \\
\text { yang menguntungkan }\end{array}$ \\
\hline & & $\begin{array}{l}\text { Responsiveness } \\
\text { (Ketanggapan) }\end{array}$ & $\begin{array}{l}\text { Produk tabungan } \\
\text { mudharabah dapat } \\
\text { memenuhi kebutuhan } \\
\text { personal nasabah }\end{array}$ \\
\hline \multirow[t]{5}{*}{2} & Bagi Hasil $\left(\mathrm{X}_{2}\right)$ & Persentase bagi hasil & $\begin{array}{lr}\text { Nisbah } & \text { keuntungan } \\
\text { didasarkan } & \text { dalam }\end{array}$ \\
\hline & $\begin{array}{l}\text { Menurut } \\
\text { Karim (2007) }\end{array}$ & & bentuk persentase \\
\hline & & $\begin{array}{l}\text { Bagi untung dan } \\
\text { bagi rugi }\end{array}$ & $\begin{array}{l}\text { Nasabah mengharapkan } \\
\text { imbalan atau return } \\
\text { yang secara akumulatif } \\
\text { dapat memperbesar } \\
\text { jumlah tabungan }\end{array}$ \\
\hline & & Jaminan & $\begin{array}{l}\text { Jaminan yang diberikan } \\
\text { bank tidak merugikan } \\
\text { nasabah }\end{array}$ \\
\hline & & $\begin{array}{l}\text { Menentukan } \\
\text { besarnya nisbah } \\
\text { keuntungan }\end{array}$ & $\begin{array}{lr}\text { Nisbah bagi hasil yang } \\
\text { ditawarkan } & \text { bank } \\
\text { menarik } & \text { untuk } \\
\text { menabung. } & \end{array}$ \\
\hline
\end{tabular}




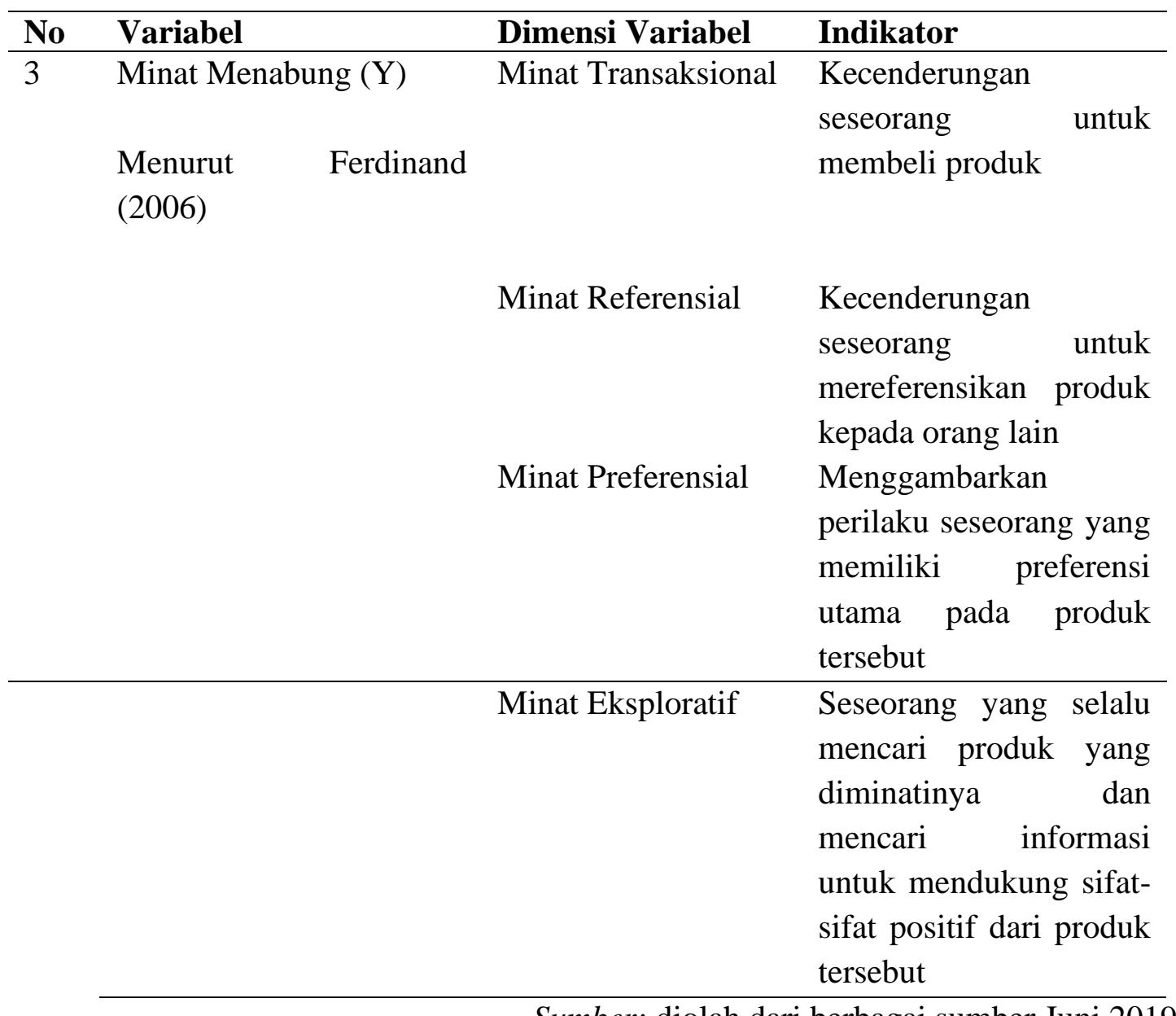

Sumber: diolah dari berbagai sumber Juni 2019

\section{HASIL DAN PEMBAHASAN}

\section{Uji Validitas}

Pada penelitian ini menggunakan metode pengukuran validitas kuesioner dengan menguji validitas butir pernyataan yang bertujuan untuk mengukur seberapa tepat suatu variabel terprediksi oleh variabel lain error yang relatif kecil. Suatu kuesioner dikatakan valid jika pernyataan pada kuesioner mampu untuk mengungkapkan sesuatu yang akan diukur oleh kuesioner tersebut (Ghozali, 2017:52)

Setiap butir pernyataan dikatakan valid apabila $f_{\text {hitung }}>f_{\text {tabel }}$. Jumlah sampel $(n)=30$ dan besarnya df dapat dihitung dengan rumus df $=\mathrm{n}-2$, yaitu 30-2 $=27$ dan alpha 0,05 didapat $r_{\text {tabel }}=0,3610$, atau dengan kata lain nilai korelasi (r) masing-masing pernyataan harus $>0,3610$. Setelah dilakukan uji validitas, maka dapat dikatakan 27 pernyataan pada penelitian ini valid karena nilai korelasinya $>0,3610$. Pernyataan pada penelitian ini dikatakan valid karena korelasinya $>0,36$. 
AL-INFAQ: Jurnal Ekonomi Islam, (p-ISSN: 2087-2178, e-ISSN: 2579-6453)

Vol. 11 No. 1 (2020)

Hasil Uji Validitas adalah sebagai berikut:

Tabel 3. Uji Validitas Variabel Kualitas Pelayanan

\begin{tabular}{|c|c|c|c|}
\hline Uraian & r Korelasi Total & $\begin{array}{l}\text { Standar } \\
\text { Pengukuran }\end{array}$ & Keterangan \\
\hline KP1 & 0,363 & 0,3610 & Valid \\
\hline KP2 & 0,419 & 0,3610 & Valid \\
\hline KP3 & 0,499 & 0,3610 & Valid \\
\hline KP4 & 0,406 & 0,3610 & Valid \\
\hline KP5 & 0,448 & 0,3610 & Valid \\
\hline KP6 & 0,496 & 0,3610 & Valid \\
\hline KP7 & 0,454 & 0,3610 & Valid \\
\hline KP8 & 0,540 & 0,3610 & Valid \\
\hline KP9 & 0,513 & 0,3610 & Valid \\
\hline KP10 & 0,490 & 0,3610 & Valid \\
\hline KP11 & 0,537 & 0,3610 & Valid \\
\hline KP12 & 0,365 & 0,3610 & Valid \\
\hline KP13 & 0,407 & 0,3610 & Valid \\
\hline KP14 & 0,596 & 0,3610 & Valid \\
\hline KP15 & 0,718 & 0,3610 & Valid \\
\hline KP16 & 0,537 & 0,3610 & Valid \\
\hline KP17 & 0,719 & 0,3610 & Valid \\
\hline KP18 & 0,562 & 0,3610 & Valid \\
\hline
\end{tabular}

Sumber: data diolah dengan SPSS 23 
AL-INFAQ: Jurnal Ekonomi Islam, (p-ISSN: 2087-2178, e-ISSN: 2579-6453)

Vol. 11 No. 1 (2020)

Tabel 4. Hasil Uji Validitas Variabel Bagi Hasil

\begin{tabular}{llll}
\hline Uraian & r Korelasi Total & $\begin{array}{l}\text { Standar } \\
\text { Pengukuran }\end{array}$ & Keterangan \\
\hline B1 & 0,400 & 0,3610 & Valid \\
B2 & 0,445 & 0,3610 & Valid \\
B3 & 0,486 & 0,3610 & Valid \\
B4 & 0,400 & 0,3610 & Valid \\
B5 & 0,387 & 0,3610 & Valid \\
B6 & 0,593 & 0,3610 & Valid \\
B7 & 0,478 & 0,3610 & Valid \\
B8 & 0,400 & 0,3610 & Valid \\
B9 & 0,489 & 0,3610 & Valid \\
B10 & 0,543 & 0,3610 & Valid \\
B11 & 0,489 & 0,3610 & Valid \\
B12 & 0,585 & 0,3610 & Valid \\
\hline
\end{tabular}

Sumber: data diolah dengan SPSS 23

Tabel 5. Hasil Uji Validitas Variabel Minat Menabung

\begin{tabular}{llll}
\hline Uraian & r Korelasi Total & $\begin{array}{l}\text { Standar } \\
\text { Pengukuran }\end{array}$ & Keterangan \\
\hline MN1 & 0,391 & 0,3610 & Valid \\
MN2 & 0,367 & 0,3610 & Valid \\
MN3 & 0,407 & 0,3610 & Valid \\
MN4 & 0,389 & 0,3610 & Valid \\
MN5 & 0,697 & 0,3610 & Valid \\
MN6 & 0,732 & 0,3610 & Valid \\
MN7 & 0,661 & 0,3610 & Valid \\
MN8 & 0,612 & 0,3610 & Valid \\
MN9 & 0,684 & 0,3610 & Valid \\
\hline
\end{tabular}

Sumber: data diolah dengan SPSS 23 


\section{Uji Reliabilitas}

Dari hasil pengolahan data validitas dan reliabilitas kuisioner dengan program SPSS versi 23 diketahui bahwa seluruh variabel dinyatakan reliabel sebagaimana dijelaskan dalam tabel dibawah ini:

Tabel 5. Uji Reliabilitas

\begin{tabular}{lll}
\hline Variabel & Alpha Cronbach & Keterangan \\
\hline Kualitas Pelayanan & 0,825 & Reliabel \\
Bagi Hasil & 0,701 & Reliabel \\
Minat Menabung & 0,722 & Reliabel \\
\hline
\end{tabular}

Berdasarkan Tabel 5 diatas diketahui bahwa nilai alpha cronbach seluruh variabel berada diatas 0,60 sehingga pengukuran seluruh variabel dinyatakan reliable atau konsisten dan memiliki keandalan.

\section{Uji Asumsi Klasik}

\section{Uji Normalitas}

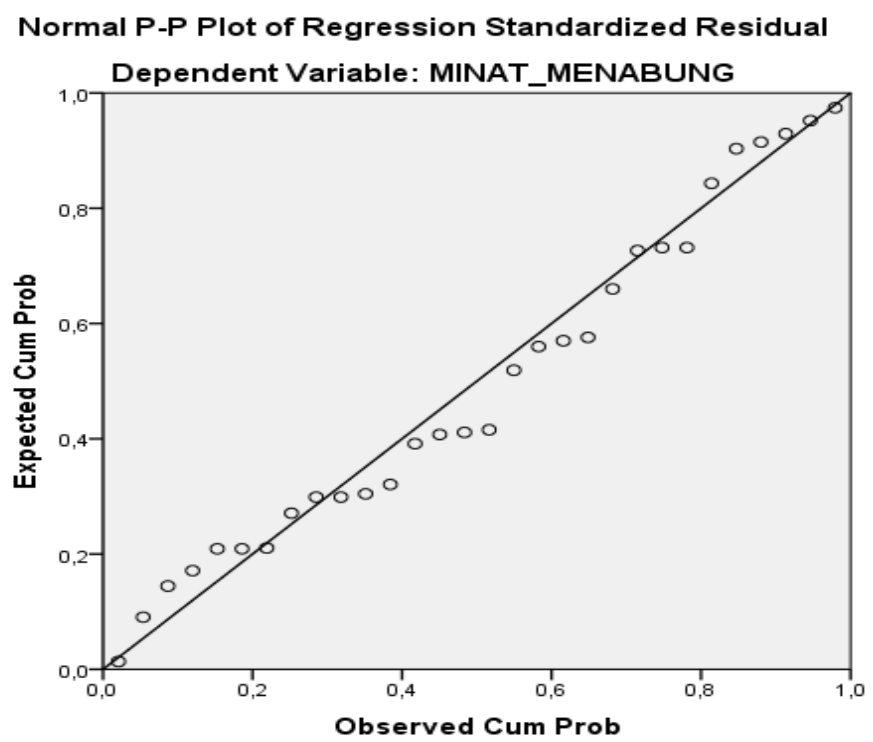

Gambar 1. Grafik P-P Plot

Sumber: data dioah dengan SPSS 23 
Dari gambar grafik 1 menunjukkan pola grafik P-P Plot yang normal, terlihat dari titik distribusi data menyebar disekitar garis diagonal dan penyebarannya mengikuti garis diagonal. Hal ini menunjukkan bahwa data berdistribusi normal dan asumsi normalitas terpenuhi.

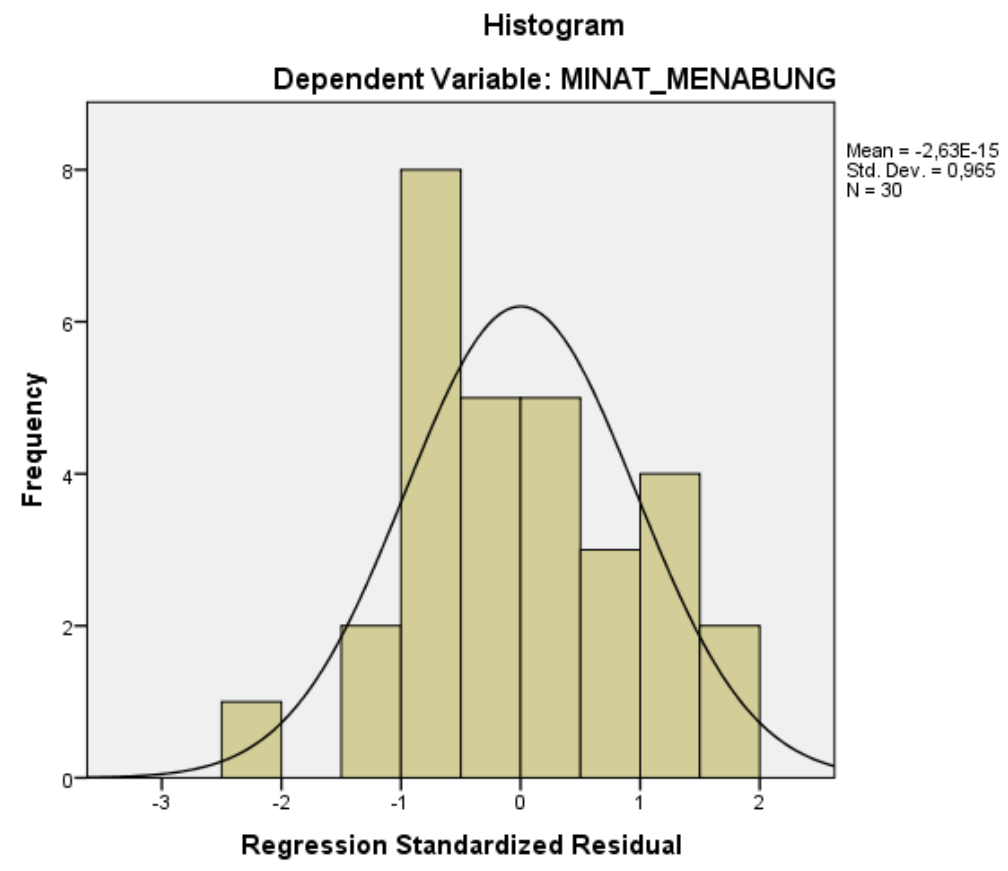

Gambar 2. Histogram

Sumber: data diolah dengan SPSS 23

Dari gambar grafik histogram dapat dilihat bahwa perbandinga antara data observasi dengan distribusi normal. Terlihat bahwa grafik hostogram menunjukkan pola distribusi yang mendekati normal, sehingga bisa disimpulkan bahwa model regresi memenuhi asumsi klasik.

\section{Uji Multikolinearitas}

Tabel 5. Uji Multikolinearitas

\begin{tabular}{|c|c|c|c|c|c|c|c|c|}
\hline \multicolumn{9}{|c|}{ Coefficients $^{\mathrm{a}}$} \\
\hline \multirow[b]{2}{*}{ Model } & & \multicolumn{2}{|c|}{ Unstandardized Coefficients } & $\begin{array}{l}\text { Standardized } \\
\text { Coefficients }\end{array}$ & \multirow[b]{2}{*}{$t$} & \multirow[b]{2}{*}{ Sig. } & \multicolumn{2}{|c|}{ Collinearity Statistics } \\
\hline & & B & Std. Error & Beta & & & Tolerance & VIF \\
\hline 1 & (Constant) & -131 & 1,132 & &,- 115 & .909 & & \\
\hline & KUALITAS_PELAYANAN & .650 & 241 & .433 & 2,697 & .012 & .891 & 1,122 \\
\hline & BAGI_HASIL &, 446 &, 226 &, 317 & 1,976 & ,058 &, 891 & 1,122 \\
\hline
\end{tabular}

Sumber: data diolah dengan SPSS 23

Keterangan pada tabel 5 menjelaskan bahwa nilai tollarance variabel Kualitas Pelayanan $\left(\mathrm{X}_{1}\right)$, Bagi Hail $\left(\mathrm{X}_{2}\right)$, Minat Menabung $(\mathrm{Y})$ lebih kecil dari 10 maka dapat dikatakan tidak terjadi multikolinearitas pada seluruh variabel bebas tersebut. 


\section{Uji Hipotesis}

\section{Analisis Regresi Linear Berganda}

Tabel 7. Hasil Analisis Regresi Linear Berganda

\begin{tabular}{|c|c|c|c|c|c|c|}
\hline \multirow{2}{*}{\multicolumn{2}{|c|}{ Model }} & \multicolumn{2}{|c|}{$\begin{array}{c}\text { Unstandardized } \\
\text { Coefficients }\end{array}$} & \multirow{2}{*}{\begin{tabular}{|c|}
$\begin{array}{c}\text { Standardized } \\
\text { Coefficients }\end{array}$ \\
Beta \\
\end{tabular}} & \multirow{2}{*}{$\mathrm{t}$} & \multirow[b]{2}{*}{ Sig. } \\
\hline & & $\mathrm{B}$ & Std. Error & & & \\
\hline \multirow[t]{3}{*}{1} & (Constant) &,- 131 & 1,132 & &,- 115 & ,909 \\
\hline & KUALITAS_PELAYANAN &, 650 &, 241 & ,433 & 2,697 &, 012 \\
\hline & BAGI_HASIL & ,446 & ,226 & ,317 & 1,976 & ,058 \\
\hline
\end{tabular}

Sumber: data diolah dengan SPSS 23

Berdasarkan hasil analisis regresi linier berganda pada tabel 7, maka dapat ditulis persamaan regresinya.

Minat Menabung $=-0,131+0,650$ (kualitas pelayanan $)+0,446$ (bagi hasil $)$

Dari rumus regresi di atas dapat dinyatakan nilai koefisien regresinya sebagai berikut:

1. Nilai konstanta menyatakan bahwa jika tidak ada nilai kualitas pelayanan, bagi hasil, maka besarnya minat menabung sebesar - 0,131

2. Apabila nilai Kualitas Pelayanan mengalami kenaikan sebesar 1 maka nilai minat menabung akan mengalami kenaikan sebesar 0,650

3. Apabila nilai Bagi Hasil mengalami kenaikan sebesar 1 maka nilai keputusan nasabah akan mengalami kenaikan sebesar 0,446

\section{Uji Signifikan Parameter Individual (Uji Statistik t)}

Uji statistik t pada prinsipnya bertujuan untuk mengetahui seberapa besar pengaruhnya terhadap setiap variabel independen (bebas) secara individual atau parsial terhadap variabel dependen (terikat).

Dasar pengambilan keputusan:

Jika nilai $t_{\text {hitung }}>t_{\text {tabel }}$ maka hipotesis $(\mathrm{Ha})$ diterima $(\mathrm{H} 0)$ ditolak.

Jika nilai $t_{\text {hitung }}<\mathrm{t}_{\text {tabel }}$ maka hipotesis $(\mathrm{Ha})$ ditolak $(\mathrm{H} 0)$ diterima. atau

Jika nilai Sig. < 0,05 maka hipotesis (Ha) diterima (H0) ditolak. Jika nilai Sig. > 0,05 maka hipotesis (H0) diterima (Ha) ditolak. 
Tabel 8. Uji Signifikansi Parameter Individual (Uji Statistik t)

\begin{tabular}{|c|c|c|c|c|c|c|}
\hline \multirow{2}{*}{\multicolumn{2}{|c|}{ Model }} & \multicolumn{2}{|c|}{$\begin{array}{c}\text { Unstandardized } \\
\text { Coefficients }\end{array}$} & \multirow{2}{*}{$\begin{array}{c}\text { Standardized } \\
\text { Coefficients }\end{array}$} & \multirow[b]{2}{*}{$\mathrm{t}$} & \multirow[b]{2}{*}{ Sig. } \\
\hline & & $\mathrm{B}$ & Std. Error & & & \\
\hline \multirow[t]{3}{*}{1} & (Constant) &,- 131 & 1,132 & &,- 115 &, 909 \\
\hline & KUALITAS_PELAYANAN & ,650 & ,241 & ,433 & 2,697 & ,012 \\
\hline & BAGI_HASIL & ,446 & ,226 & ,317 & 1,976 & ,058 \\
\hline
\end{tabular}

Sumber: data diolah dengan SPSS 23

(1) Kualitas Pelayanan

Jika dilihat dari signifikansi diketahui bahwa nilai siginifikan 0,012 lebih besar dari $0,05(0,012>0,05)$ yang artinya hipotesa Ha ditolak dan Ho diterima, sedangkan nilai $t_{\text {hitung }}$ sebesar 2,697. $\mathrm{T}_{\text {tabel }}$ bisa dihitung pada tabel t-test dengan $\alpha=0,05$, dengan melihat $\mathrm{t}_{\text {tabel }}(\mathrm{df}=$ $\mathrm{n}-\mathrm{k}, 30-3=27)$. Maka didapatlah $t_{\text {tabel }}$ sebesar 0,3610 karena $t_{\text {hitung }}>t_{\text {tabel }}(0,2697<2,05553)$, maka Ho diterima sedangkan Ha ditolak. Dari penjelasan secara teori dan hasil statistik dari penelitian dapat disimpulkan bahwa karakteristik tidak memiliki pengaruh signifikan terhadap minat menabung nasabah pada tabungan marhamah.

(2) Bagi Hasil

Jika dilihat dari signifikansi diketahui bahwa nilai signifikan 0,058 lebih besar dari $0,05(0,058>0,05)$ yang artinya hipotesa Ha ditolak dan Ho diterima, sedangkan nilai $t_{\text {hitung }}$ sebesar 1,976. $\mathrm{T}_{\text {tabel }}$ bisa dihitung pada tabel t-test $\alpha=0,05$, dengan melihat tabel $(\mathrm{df}=\mathrm{n}-\mathrm{k}$, 30-3=27). Maka didapatlah $t_{\text {tabel }}$ sebesar 0,3610 karena $t_{\text {htung }}>t_{\text {tabel }}(0,317<2,05553)$, maka Ho diterima sedangkan Ha ditolak. Dari penjelasan secara teori dan hasil statistik dari penelitian dapat disimpulkan bahwa kemamouan tidak memiliki pengaruh signifikan terhadap minat menabung nasabah pada tabunga marhamah.

\section{Uji Signifikan Keseluruhan Regresi Sampel (Uji F)}

Uji statistik F pada prinsipnya bertujuan untuk mengetahui pengaruh dari dua variabel independen atau lebih secara simultan (bersama-sama) terhadap variabel dependen (Ghozali, 2017:96).

Hipotesis dalam uji $\mathrm{F}$ adalah sebegai berikut:

$\mathrm{H}_{0}$ : Variabel kualitas pelayanan, bagi hasil, minat menabung secara bersama-sama (simultan) tidak berpengaruh terhadap variabel Minat Menabung Nasabah pada tabungan marhamah Ha: Variabel kualitas pelayanan, bagi hasil, minat menabung secara bersama-sama (simultan) berpengaruh terhadap variabel minat menabung. Dasar pengambilan keputusan:

Jika nilai $F_{\text {hitung }}>F_{\text {tabel }}$ maka hipotesis $(\mathrm{Ha})$ diterima $\left(\mathrm{H}_{0}\right)$ ditolak.

Jika nilai $\mathrm{F}_{\text {hitung }}<\mathrm{F}_{\text {tabel }}$ maka hipotesis $(\mathrm{Ha})$ ditolak $\left(\mathrm{H}_{0}\right)$ diterima.

atau

Jika nilai Sig. $<0,05$ maka hipotesis $(\mathrm{Ha})$ diterima $\left(\mathrm{H}_{0}\right)$ ditolak.

Jika nilai Sig. $>0,05$ maka hipotesis $\left(\mathrm{H}_{0}\right)$ diterima $(\mathrm{Ha})$ ditolak. 
Tabel 9. Uji Signifikansi Keseluruhan dari Regresi Sample (Uji Statistik F)

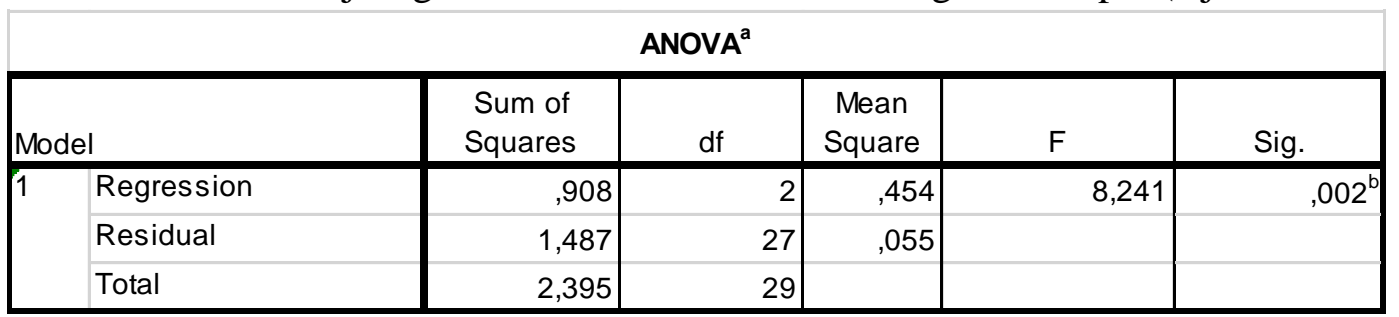

Sumber: data diolah dengan SPSS 23

Pada tabel tersebut, dapat dilihat besaran sig 0,002 hal ini menjelaskan bahwa nilai sig lebih kecil dari 0,05. Sehingga dapat disimpulkan bahwa Ho ditolak dan Ha diterima. Jadi variabel independen (Kualitas Pelayanan, Bagi Hasil secara bersama-sama mempengaruhi variabel dependen (Minat Menabung nasabah pada tabungan marhamah secara signifikan.

Dengan menggunakan tingkat keyakinan 95\%, $\alpha=5 \%$, df 1 dapat ditentukan dengan persamaan df $1=$ jumlah variabel atau df $1=2$, sedangkan df $2=n-k-1$ atau df $2=30-2-1$ sehingga diperoleh hasilnya 27. Maka dapat dilihat pada tabel $\mathrm{F}$ adalah sebesar. Berdasarkan hasil uji statistik dengan metode uji F, dimana Fhitung sebesar 8,241 lebih besar dari Ftabel yakni 3,35 maka dapat disimpulkan bahwa Ha diterima atau variabel independen (kualitas pelayanan, bagi hasil) secara bersama-sama berpengaruh signifikan terhadap variabel dependen (minat menabung).

\section{Uji Koefisien Korelasi dan Determinasi $\left(\mathbf{R}^{\mathbf{2}}\right)$}

Koefisien determinasi (R2) pada intinya mengukur seberapa jauh kemampuan model dalam menerangkan variasi variabel dependen. Nilai koefisien determinasi adalah antara nol dan satu. Nilai R2 yang kecil berarti kemampuan variabel-variabel independen dalam menjelaskan variasi variabel dependen amat terbatas. Nilai yang mendekati satu berarti variabel-variabel independen memberikan hampir semua informasi yang dibutuhkan untuk memprediksi variasi variabel dependen (Ghozali, 2017:95).

Tabel 10. Koefisien Korelasi dan Determinasi

\begin{tabular}{|c|c|c|c|c|}
\hline $\begin{array}{l}\text { Mod } \\
\text { el }\end{array}$ & $\mathrm{R}$ & R Square & $\begin{array}{l}\text { Adjusted R } \\
\text { Square }\end{array}$ & $\begin{array}{l}\text { Std. Error } \\
\text { of the } \\
\text { Estimate }\end{array}$ \\
\hline 1 &, $616^{a}$ & ,379 & ,333 & ,23468 \\
\hline
\end{tabular}

Berdasarkan tabel 10 maka diperoleh hasil sebagai berikut:

(1) Koefisien korelasi (R) sebesar 0,616 menunjukkan bahwa hubungan yang sangat kuat antara variabel independen dengan variabel dependen karena mendekati angka 1.

(2) Koefisien determinasi $\left(\mathrm{R}^{2}\right)$ sebesar 0,379 menunjukkan bahwa proporsi variabel independen menjelaskan atau mempengaruhi variabel dependen sebesar 37,9\% .

(3) Koefisien Adjusted $\mathrm{R}^{2}$ sebesar 0,333 merupakan korelasi dari $\mathrm{R}^{2}$ sehingga gambarnya lebih mendekati populasi. 


\section{PEMBAHASAN}

1. Pengaruh Kualitas Pelayanan Terhadap Minat Menabung Nasabah Pada Tabungan Marhamah

Apabila tingkat signifikansi lebih kecil dari 0,05 dan $t_{\text {hitung }}$ lebih besar dari $t_{\text {tabel }}$ maka variabel independen berpengaruh terhadap variabel dependen. Berdasarkan hasil penelitian ini diperoleh tingkat signifikansi variabel kualitas pelayanan adalah sebesar 0,012 yang

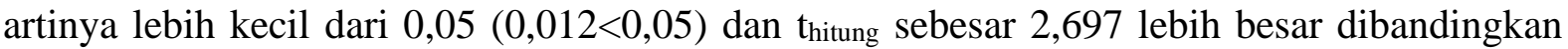
dengan $t_{\text {tabel }} 2,05553(2,697>2,05553)$, maka dapat disimpulkan bahwa variabel kualitas pelayanan berpengaruh signifikan terhadap minat menabung nasabah pada tabungan marhamah. Terdapatnya pengaruh kualitas pelayanan terhadap minat menabung nasabah pada tabungan marhamah menunjukkan bahwa kualitas pelayanan yang diberikan oleh PT Bank Sumut KCP Syariah Karya dirasakan telah memberikan pelayanan terbaik sehingga menimbulkan minat nasabah untuk menabung dalam menggunakan produk serta jasa PT Bank Sumut KCP Syariah Karya hal ini sesuai berdasarkan teori Juniawan (2014:02) yang berkesimpulan bahwa ada kebutuhan bagi bank Islam untuk menggunakan program kualitas layanan Islami. Yaitu salah satunya, produk dan layanan bank Islam harus diterima sebagai produk dan layanan yang berkualitas tinggi oleh konsumen. Konsep kerja dalam Islam di anggap sebagai salah satu jenis ibadah. Kemudian juga sesuai dengan teori Othman dan Owen yang menunjukkan setiap dimensi kualitas layanan seperti kepatuhan, jaminan, kehandalan, keberwujudan, empati, serta ketanggapan telah sesuai memberikan pelayanan yang baik dan bagus oleh PT Bank Sumut KCP Syariah Karya terhadap nasabah tabungan marhamah.

Hasil penelitian sesuai dengan penelitian yang dilakukan oleh Nasution (2018) bahwa variabel kualitas pelayanan secara parsial memiliki nilai signifikansi sebesar $0,03<0,05$. Hal ini berarti bahwa variabel kualitas pelayanan berpengaruh signifikan terhadap kepuasan nasabah tabungan mudharabah (Studi Kasus PT Bank Syariah Mandiri KCP Simpang Limun).

Hal ini juga sejalan dengan penelitian Daulay (2014) yang menyatakan bahwa variabel kualitas pelayanan secara parsial memiliki nilai signifikansi sebesar 0,002 < 0,05. Hal ini berarti bahwa variabel kualitas pelayanan berpengaruh signifikan terhadap keputusan menabung pada PT Bank Mandiri Syariah di Kota Medan.

Hal ini juga sejalan dengan penelitian yang dilakuka.an oleh Sofiyanto et.al (2016) yang menyatakan bahwa variabel kualitas pelayanan secara parsial memiliki nilai signifikansi sebesar $0,001<0,05$. Hal ini berarti bahwa variabel kualitas pelayanan berpengaruh secara signifikan terhadap kepuasan nasabah kredit kepemilikan rumah (Studi Empiris pada PT Bank Tabungan Negara (Persero) Cabang Semarang).

Hal ini juga sejalan dengan penelitian yang dilakukan oleh Perdana dan Prayitno (2014) yang menyatakan bahwa variabel kualitas pelayanan secara parsial memiliki nilai signifikansi sebesar $0,019<0,05$. Hal ini berarti bahwa variabel kualitas pelayanan berpengaruh secara signifikan terhadap kepuasan nasabah pada Bank Victoria Syariah di Brebes. 
Hal serupa juga sejalan dengan penelitian yang dilakukan oleh Zulfah (2008) yang menyatakan bahwa variabel kualitas pelayanan secara parsial memiliki nilai signifikansi sebesar $0,000<0,05$. Hal ini berarti bahwa variabel kualitas pelayanan berpengaruh secara signifikan terhadap kepuasan nasabah Tabungan Haji pada PT BNI Syariah Tbk Cabang Jakarta Timur

\section{Pengaruh Bagi Hasil Terhadap Minat Menabung Nasabah Pada Tabungan Marhamah}

Apabila tingkat signifikansi lebih kecil dari 0,05 dan $t_{\text {hitung }}$ lebih besar dari tabel maka variabel independen berpengaruh terhadap variabel dependen. Berdasarkan hasil penelitian ini diperoleh tingkat signifikansi variabel bagi hasil adalah sebesar 0,058 yang artinya lebih besar dari $0,05(0,058<0,05)$ dan $t_{\text {hitung }}$ sebesar 1,976 lebih besar dibandingkan dengan $t_{\text {tabel }}$ 2,05553 (1,976 > 2,05553), maka dapat disimpulkan bahwa variabel bagi hasil berpengaruh signifikan terhadap minat menabung nasabah pada tabungan marhamah. Terdapatnya bagi hasil terhadap minat menabung nasabah pada tabungan marhamah menunjukkan bahwa bagi hasil yang diberikan oleh PT Bank Sumut KCP Syariah Karya dirasakan telah memberikan bagi hasil yang memuaskan sehingga menimbulkan minat nasabah untuk menabung dalam menggunakan produk serta jasa PT Bank Sumut KCP Syariah Karya hal ini sesuai berdasarkan teori Nikensari (2012:24) yang berkesimpulan hal lain yang bisa saja mempengaruhi minat menabung salah satunya bagi hasil. Bagi hasil adalah kerja sama antara dua belah pihak yang satu sebagai penyandang dana dan yang lain sebagai pengelola dimana hasil usahanya akan dibagi sesama sesuai yang telah disepakati. Kemudian juga sesuai dengan teori Karim yang menunjukkan setiap dimensi bagi hasil seperti persentase bagi hasil, bagi untung dan bagi rugi, jaminan, menentukan besarnya nisbah keuntungan yang bagus dan memuaskan yang diberikan oleh PT Bank Sumut KCP Syariah Karya.

Hasil penelitian sesuai dengan penelitian yang dilakukan oleh Daulay (2014) bahwa variabel bagi hasil secara parsial memiliki nilai signifikansi sebesar $0,000<0,05$. Hal ini berarti bahwa variabel bagi hasil berpengaruh signifikan terhadap keputusan menabung nasabah pada Bank Syariag Mandiri di Kota Medan.

Hal serupa juga sejalan dengan penelitian yang dilakukan oleh Perdana (2014) yang menyatakan bahwa variabel bagi hasil secara parsial memiliki nilai signifikansi sebesar 0,000 $<0,05$. Hal ini berarti bahwa variabel bagi hasil berpengaruh secara signifikan terhadap kepuasan nasabah pada Bank Victoria Syariah di Brebes.

\section{Pengaruh Kualitas Pelayanan dan Bagi Hasil Terhadap Minat Menabung Nasabah pada Tabungan Marhamah}

Apabila tingkat signifikansi lebih kecil dari 0,05 dan F hitung lebih besar dari F tabel, maka variabel independen berpengaruh secara simultan terhadap variabel dependen. Berdasarkan hassil penelitian ini diperoleh tingkat signifikansi variabel 0,335 yang artinya lebih besar dari 0,05 $(0,335>0,05)$ dan $F$ hitung sebesar 8,241 dibandingkan $F$ tabel 0,335 $(8,241>0,335)$, maka dapat disimpulkan bahwa variabel kualitas pelayanan dan bagi hasil secara simultan berpengaruh signifikan terhadap minat menabung nasabah pada tabungan marhamah PT Bank Sumut KCP Syariah Karya. 
Hasil penelitian ini secara simultan menunjukkan perbandingan yang berbeda dari penelitian yang dilakukan oleh Daulay (2014) yang menyatakan bahwa variabel kualitas pelayanan dan bagi hasil secara simultan memiliki nilai signifikan sebesar $0,000<0,05$. Hal ini berarti bahwa variabel kualitas pelayanan sebagai $\left(\mathrm{X}_{1}\right)$ dan bagi hasil sebagai $\left(\mathrm{X}_{2}\right)$ secara simultan berpengaruh signifikan terhadap keputusan menabung nasabah pada Bank Syariah Mandiri di Kota Medan.

\section{KESIMPULAN}

Berdasarkan pengolahan data dan hasil analisis data yang mengacu pada masalah dan tujuan penelitian, maka dapat diambil kesimpulan sebagai berikut:

1. Variabel kualitas pelayaanan menunjukkan berpengaruh signifikan terhadap minat menabung nasabah pada tabungan marhamah PT Bank Sumut KCP Syariah Karya dengan nilai signifikansi sebesar 0,012 .

2. Variabel bagi hasil menunjukkan berpengaruh signifikan terhadap minat menabung nasabah pada tabungan marhamah PT Bank Sumut KCP Syariah Karya dengan nilai signifikansi sebesar 0,058

3. Variabel kualitas pelayanan dan bagi hasil berpengaruh secara bersama-sama (simultan) terhadap minat menabung nasabah pada tabungan marhamah PT Bank Sumut KCP Syariah Karya dengan nilai signifikansi sebesar 0,012, dengan korelasi yang kuat. Koefisien determinasi sebesar 33,3\%.

\section{DAFTAR PUSTAKA}

Al-Qur'an, dan terjemahan 2013. Jakarta: Departemen Agama RI

Al-Qardhawi, Yusuf. 2001. Bunga Bank Haram. Alih bahasa Setiawan Budi

Utomo. Cetakan Pertama. Jakarta: Akbar.

Daulay, Raihanah. 2014. "Pengaruh Kualitas Pelayanan dan Bagi Hasil Terhadap Keputusan Menabung Pada Bank Mandiri Syariah di Kota Medan" Jurnal Riset Akuntasi dan Bisnis.

Ferdinand, Agusty. 2006. Metode Penelitian Manajemen

Ghozali, Imam. 2017. Aplikasi Analisis Multivariete Dengan Program IBM SPSS 23. Semarang: Badan Penerbit Universitas Diponogoro.

Harahap, Raidatus Syifa. 2018. Analisis Pengaruh Kualitas dan Islamic Compliance Terhadap Kepuasan Nasabah PT Bank Sumut Kantor Cabang Syariah Medan. Jurusan Akuntansi. Politeknik Negeri Medan.

Ismail. 2011. Perbankan Syariah. Jakarta: Kencana.

Karim, Adiwarman A. 2007. Ekonomi Mikro Islam. Jakarta: Raja Grafindo Persada.

Kharisma Mahkota Perdana dan Agus Prayitno. 2014. Pengaruh Kualitas Pelayanan, Nilai Nasabah dan Bagi Hasil terhadap Kepuasan Nasabah Pada Bank Victoria Syariah di Brebes.

Nasution, Inanta Hardianti. 2018. Pengaruh Kualitas Pelayanan Dan Bagi Hasil Terhadap Kepuasan Nasabah Tabungan Mudharabah (Studi Kasus Pt Bank Syariah Mandiri Kcp Simpang Limun). Jurusan Akuntansi. Politeknik Negeri Medan.

Nikensari, Sri Indah. 2012. Perbankan Syariah Prinsip, Sejarah dan Aplikasinya. Semarang: PT. Pustaka Rizki Putra 
Othman, A.Q., dan Owen, L., 2001, Developing an Instrument to Measure Customer Service Quality (SQ) in Islamic Banking, International Journal of Islamic Financial Services, Vol. 3, April and June.

PT Bank Sumut Cabang Pembantu Syariah Karya

Rivai, Veithzal dan Arviyyan Arifin. 2010. Islamic Banking. Sebuah teori, konsep dan aplikasi. Jakarta: Bumi Aksara.

Rianty, Adella. 2017.Pengaruh Kualitas Pelayanan Dan Bagi Hasil Terhadap Kepuasan Nasabah Tabungan Mudharabah Studi Kasus Pada PT. Bank Syariah Mandiri di Wilayah Tangerang Selatan. Universitas Islam Negeri Syarif Hidayatullah Jakarta.

Sugiyono.2017. Metode Penelitian Kuantitatif, Kualitatif, dan R\&D. Bandung: Alfabeta.

Sanusi, Anwar. 2011. Metedologi Penelitian Bisnis Metodologi Penelitian Bisnis. Jakarta Selatan: Salemba Empat.

Setiawan, Mulyo Budi. dan Ukudi. 2007. "Pengaruh Kualitas Layanan, Kepercayaan dan Komitmen Terhadap Loyalitas Nasabah (Studi Pada PD. BPR Bank Pasar Kendal)”. Jurnal Bisnis dan Ekonomi (JBE). Vol. 14. No.2.

Sofiyanto, Aziz Fathoni, dan Andi Tri Haryono. 2016. Lokasi, Tingkat Suku Bunga, Kualitas Pelayanan Terhadap Kepuasan Nasabah Kredit Kepemilikan Rumah (Studi Empiris pada PT. Bank Tabungan Negara (Persero) Cabang Semarang)

Zainal, Veith Rival, dkk. 2017. Islamic Marketing Management: Mengembangkan Bisnis dengan Hijrah Kepemasaran Islami Mengikuti Praktik Rasulullah swa. Jakarta: Bumi Aksara.

Zulfah, Lailatul. 2008. Pengaruh Kualitas Produk dan Kualitas Pelayanan Terhadap Kepuasan Nasabah Tabungan Haji pada PT BNI Syariah 